\title{
Political-Ideological Circumstances and Local Authorities' Debt: Evidence from Portuguese Municipalities
}

\author{
Nuno Adriano Baptista Ribeiro ${ }^{1,2}$, Susana Margarido Faustino Jorge ${ }^{3,4}$
}

\begin{abstract}
The objective of this research is to analyze whether the political-ideological situation of municipalities affects their debt level, considering evidence from Portugal for the period 2004-2013. A static panel data model is applied, incorporating factors such as political ideology, political-electoral cycle, governance format, coincidence of the political parties between Local Executive and Local Assembly and coincidence of the political parties between the Local Executive and Central Government. An additional variable to control the effects of the economic crisis between 2008 and 2010 is also considered. Based on the assumptions of the public choice theory, findings show a statistically significant relationship for the political-electoral cycle, allowing the conclusion that, given the evidence from Portuguese municipalities, debt increases in election years. Nevertheless, this is the only factor in the political-ideological circumstances that was found to be relevant in its effect on local authorities' debt levels. It is also clear that the financial crisis in the period 2008-2010 likewise had a positive impact.

The paper contributes to the strengthening of the debate on the association between municipalities' political circumstances and debt, namely, in regards to strategic (electoral) debt cycles in local government.
\end{abstract}

KEY WORDS: $\quad$ Debt, Local Government, Political-Ideological Factors, Public Finance

JEL Classification: $\quad$ H74, H83

${ }^{1}$ Polytechnic Institute of Bragança, Portugal; ${ }^{2}$ UNIAG - Management and Applied Research Unit, Portugal; ${ }^{3}$ Faculty of Economics, University of Coimbra, Portugal; ${ }^{4} \mathrm{CICP}$-Research Centre in Political Science, University of Minho, Portugal

\section{Introduction}

The international economic panorama, namely, the high levels of public debt in various countries, has led to increased interest in studying this topic. Thus, a considerable amount of research has tried to analyze debt 口 in both central and local governments.

Correspondence concerning this article should be addressed to: Nuno Adriano Baptista Ribeiro, Instituto Politécnico de Bragança, Campus de Santa Apolónia - Apartado 1134, Bragança 5300-857, Portugal.E-mail: nunoa@ipb.pt
Concerning the analysis of debt in Local Government, there have been various types of studies. Most are related to the hypothesis of the existence of strategic debt (political) cycles, to the identification of determinant factors, attempting to understand how they influence debt, and to the subject of institutional restrictions imposed on debt levels, fundamentally by the State but also, for example, by financial markets.

The emergence of the public choice theory led to new, fundamentally positive, approaches (Veiga \& Veiga, 2005). Accordingly, greater importance is given 
to individuals (politicians, electors, citizens, etc.) being selfish and rational in the attempt to maximize utility (Mueller, 1976). Based on this idea, Musgrave and Musgrave (1989) indicate that politicians try to maximize votes (adopting opportunistic behavior) to reach power and maintain it.

In this context, it is evident that political factors can be the basis for setting public policies, namely, economic/budgetary ones. This study draws upon this idea, aiming to understand whether the municipalities' political-ideological circumstances (namely, political ideology, political-electoral cycle, form of governance, the political party of the Executive in face of the majority in the Municipal Assembly, and the political party leading the Municipal Executive in face of the party in Central Government) affect their debt levels. Data from Portuguese municipalities are used, covering the period 2004 to 2013, with panel data analysis models. This methodology was found to be adequate as it allows simultaneous analysis of inter-municipal (cross-sectional dimension) and over time variations (temporal dimension).

The institutional and legal framework of municipalities' debt in Portugal is regulated by the financial regime established in the Local Finance Law (Diário da República, 2007). According to this, as well as to the Constitution, municipalities have financial autonomy, meaning that they run their own budget, expenditures and property, they can levy taxes within the legal limits, and they can contract debt also according to the requirements within their financial regime (Article 3). Under the principle of national solidarity, local finances have to be coordinated with the State's finances, contributing to the balance and financial sustainability of the public sector accounts as a whole (Article 5).

Municipalities' debt might embrace long- and short-term bank loans, financial leasing, local bonds and current debt to suppliers. Debt limits are established by law (Articles 36-37), and the regime for loans is likewise regulated (Articles 38-39). In the case of exceeding debt limits or risking default, municipalities have to present to the Local Government General Department a plan for financial recovery (Articles 4041) given that the State does not assume responsibility for any of their liabilities or commitments (Article 43). Any deviations from the targets established in the financial recovery plan may lead to a penalty by the Central Government, which retains part of the transfers the municipality is entitled to until the situation is settled (Article 41).

The Central Government can, however, create some lines of support, in the form of subsidies of especial loans, to allow for the financial recovery of those municipalities in more financial difficulties, which has happened in the last five years, with some supporting financial programs, such as PAEL (Carvalho et al., 2014).

In the last decade, Portuguese municipalities' debt has been approximately $2 / 3$ long-term bank loans and financial leasing and $1 / 3$ current debt to suppliers and short-term bank loans, reaching the highest amount in 2010 with 8,693 million euros. Financial independency (the rate of proper revenue over total revenue) has been on average $33 \%$ since 2007 , with a minimum of $31 \%$ in 2009 when debt reached the highest level of $11 \%$; on average, transfers and grants from the Central Government have ranged between $58 \%$ of the total revenue in 2009 and $64 \%$ in 2012 . Financial dependency from these transfers and grants is high in small municipalities (below 20,000 inhabitants); on average, approximately $70 \%$; large municipalities (above 150,000 inhabitants) almost reach this average for financial independency; that is, proper revenue has been over $60 \%$ since 2007 given that in large cities, they benefit from higher rates and amounts of property taxes (Carvalho et al., 2014).

The clearly limited studies about local debt, especially those carried out in Portugal, and the growing international interest in studying the behavior of local authorities' debt, create an opportunity for this paper to make a significant contribution. A particularity of this investigation, which may also be considered an important addition to the international literature, is the use of a dependent variable (net per capita debt) that is calculated based on the balance sheet and not on the budget accomplished, as previous studies have done $^{1}$. Given that it is based on the information contained in each municipality balance sheet, which these authorities only started to elaborate after publication of the Official Chart of Accounts for Local Government (POCAL) ${ }^{2}$, the period of study became limited at the beginning because it is believed that municipalities' financial statements began presenting more complete and reliable information from 2004 
Following this introduction, section 2 addresses a brief literature review on the public choice theory and on the political-ideological determinants of municipal debt. Methodological issues are described in section 3 , namely, the research problem and objective, the hypotheses and variables, and the method of statistical treatment. Section 4 presents the results and discusses the hypotheses. Finally, the main conclusions are summarized, and some lines of further development of the research are suggested in section 5 .

\section{Literature review}

\subsection{Theory of public choice}

The theory of public choice developed in particular from the works of Buchanan and Tullock (1962) and Ostrom (1971). Mueller (1976) explains that this theory studies the process related to decision-making in political contexts, using theoretical and methodological assumptions originating in economic science. In this context, Musgrave and Musgrave (1989) add that political competence allows politicians to act according to electors' interests, just as economic competence is based on consumers' preferences in defining the supply.

The basic postulates associated with the public choice consider, as in economic theory, the individual to be selfish, rational and maximizing utility (Mueller 1976). From this idea, Musgrave and Musgrave (1989) argue that politicians try to maximize votes to achieve power and maintain it. As for electors, they vote for the politicians they believe best represent their interests.

According to Pereira (1997), the democratic political process may be analyzed as a competitive market, in which politicians, citizens, civil servants and others, have fundamentally egocentric motivations.

Therefore, based on the ideas presented above, the analysis of the political process, elaborated within the scope of the theory of public choice, is found to follow the same principles as agency theory ${ }^{3}$ (Ferreira, 2011a). In these terms, the politician is the agent, while the principals are citizens/electors, opposition parties, creditors, control organs and non-governmental organizations, among others. For Zimmerman (1977), delegation of authority by citizens to politicians may create an agency problem, with the expectation that the agent (politician) will not always act in the best interests of the principal (citizens, electors, etc.).
For Ferreira (2011a), a consequence of the positive approach to the theory of public choice ${ }^{4}$ is that the politician is motivated to manipulate economic policies to his own advantage in an attempt to maximize votes (which is opportunistic behavior according to Serralde Miguez (2000). Considering that votes can be won through public expenditures and can generally be lost through visible tax increases, in democratic regimes, there is a tendency to create budget deficits. In addition, governments get involved in political-economic cycles, characterized by increased public spending/debt in the pre-election period, followed by inflationist tension and restrictive policies after the election (Pereira, 1997). Based on this type of action, the possibility arises of economic cycles conditioned by electoral periods, i.e., political-budgetary cycles (Rogoff, 1990).

In the sphere of political-budgetary cycles, a line of research emerged relating the study of debt to political cycles. This line of research, introduced by Persson and Svensson (1989), in a study applied to Central Government, is normally referred to as 'strategic cycles of debt'. The basic idea of the main models is that politicians in power try to create limitations for future governments by resorting to debt. The amount of debt will be greater, the greater the ideological difference in relation to the composition of public expenditures (Ashworth, Geys, \& Heyndels, 2005; Escudero Fernández and Prior Jiménez, 2002; Persson \& Svensson, 1989).

Following the work by Persson and Svensson (1989), the line of research regarding strategic cycles of debt has developed considerably, particularly with the works of Alesina and Tabellini (1990), Aghion and Bolton (1990), Milesi-Ferreti (1995), Martimort (2001), Sutter (2003) and Lami and Imami (2013), among others.

The study of strategic cycles of debt has also emerged in research applied to Local Government, initiated by the work of Pettersson-Lidbom (2001), which was followed by many others, namely, Salinas Jiménez and Álvarez García (2002), Escudero Fernández and Prior Jiménez (2002), Fernández Llera, García Valiñas and Cantarero Prieto (2003; 2004), Borge (2005), Ashworth et al. (2005), Goeminne and Smolders (2008), Vila i Vila (2010) and Sánchez Mier (2011). In several studies, the analysis of the strategic cycle of debt is related to political parties and to governments' political strength (Benito, Bastida, \& Muñoz, 2010). 


\subsection{The political-ideological situation and municipal debt}

Public choice theory, as one explanatory theory of debt, allows identification of a range of factors able to influence debt levels in the context of Local Government.

According to Vallés Giménez (2002), the various determinant factors of debt can be grouped into three types: institutional, fiscal and economic. At the same time, however, the same author considers this classification to be subject to personal interpretation, and so, there could be many others. The interpretation of Fernández Llera et al. $(2003 ; 2004)$ led them to group factors in the same way as Vallés Giménez (2002), having studied socio-economic (institutional and economic), political and budgetary (financial) factors. Zafra Gómez, Plata Díaz and Pérez López (2009), in turn, consider the determinant factors of debt can be divided into external and internal. External aspects include those of a social, economic and political nature. Variables related to entities' financing are considered internal. Ribeiro (2012) presents a model of structural equations, identifying the different situations able to influence municipal debt. He therefore studies institutional, fiscal, budgetary and economic situations.

Although the situations and determinants that might influence debt may be of different natures, the current study focuses on determinants related to the political-ideological situation. Bearing in mind the statistically non-significant results of other studies, it intends to show that the ideological-political stability prevailing in the Portuguese municipalities configures a greater influence of such factors in relation to debt.

In this context, the factors included in the politicalideological setting and considered determinants of debt are generally related to the form of governance, political ideology and electoral cycles. These factors have been studied by various authors, highlighting that the results obtained are not always significant and are often in disagreement.

Political ideology is certainly one of the most studied factors in the international literature. Authors such as López Laborda and Vallés Giménez (2002), Salinas Jiménez and Álvarez García (2002, 2003), Ashworth et al. (2005), Hagen and Vabo (2005), Geys (2007), Tovmo (2007), Vila i Vila (2010), Ferreira (2011b), Guillamón, Benito, \& Bastida (2011) and Bastida, Beyaert,
\& Benito (2013) distinguish parties on the right and on the left, attempting to assess how their ideological action is associated with debt. The basic hypothesis does not coincide in the different studies; therefore, Vallés Giménez (2002) and López Laborda and Vallés Giménez (2002) raise some doubts as to which parties have a greater tendency toward debt, concluding that the sign of the relationship with debt will be indeterminate. Feld and Kirchgässner (2001), PetterssonLidbom (2001), Salinas Jiménez and Álvarez García (2002, 2003), Hagen and Vabo (2005), Ashworth et al. (2005), Geys (2007), Tovmo (2007) and Vila i Vila (2010) start from the idea that left-wing parties, being more in favor of public intervention, will be more likely to present higher levels of debt. The same hypothesis was assumed by Kieweit and Szakaly (1996), Bastida Albadalejo and Benito López (2005), Zafra Gómez et al. (2011), Letelier (2011) and Sánchez Mier (2011), recognizing that progressive parties, usually favoring a larger public sector with increased functions, will present higher levels of debt than conservative parties.

Kieweit and Szakaly (1996) validated the hypothesis that conservative parties are less prone to debt. In turn, Ashworth et al. (2005) obtained a result they classify as unexpected; they found that left-wing parties, even with higher levels of expenditure, presented lower debt. This was also concluded by Pettersson-Lidbom (2001), showing that right-wing parties increased debt when they anticipate losing the election. As to the remaining analysis from the authors mentioned above, they did not allow validating any of the hypotheses established because the results were not statistically significant. So, they did not find evidence that parties' ideological differentiation interfered in any way in debt.

The relationship between political cycles and debt was studied by authors such as Pettersson-Lidbom (2001), Vallés Giménez (2002), López Laborda and Vallés Giménez (2002), Salinas Jiménez and Álvarez García (2002; 2003), Fernández Llera et al. (2003; 2004), Escudero Fernández and Prior Jiménez (2002b), Ashworth et al.(2005), Geys (2007), Agundez Alvarez and Baza Román (2008), Hájek and Hájková (2009), Vila i Vila (2010), Zafra Gómez et al. (2011), Letelier (2011), Ferreira (2011b), Sánchez Mier (2011) and Bastida et al. (2013). In general, they all try to validate the hypothesis that at election time, there is 

al. (2011) and Bastida et al. (2013) explain that greater strength will lead to less debt. In turn, Vallés Giménez (2002) and López Laborda and Vallés Giménez (2002) consider the same factor, designating it as the political market and purchase of votes to achieve governability through coalitions. Feld and Kirchgässner (2001) did not expect to find a significant impact of this variable on debt, as at least two of the four largest parties were part of local Executives.

Despite their initial expectation, Guillamón et al. (2011) finally obtained contrary evidence; they find that the greater the local executive strength, the greater the debt is. The authors suggest that it can be related to the fact that a stronger government may consider it has great political legitimacy and so is not averse to resorting to debt when necessary. The results obtained by the other authors did not present significant values.

\section{Research methodology}

\subsection{Problem and objective}

The issue that is the basis of this paper concerns the possibility of the political-ideological circumstances influencing debt in Local Government. Therefore, the intention is, learning from the context of Portuguese municipalities, to develop a model that can provide both local authorities' managers and external controlling bodies useful information, so that they can manage and control debt, which is a critical aspect of financial management in the public sector.

The objective, in particular, is to understand whether the political-ideological situation of municipalities influences their debt levels, using data from all 308 Portuguese municipalities for the period 2004 to $2013^{6}$.

\subsection{Hypotheses and variables}

The model's dependent variable will be net per capita debt (ENDLIQ). The calculation of this indicator was based on what is set out in the regulations in force for the jurisdiction in question, namely, the European System of National and Regional Accounts (ESA) and Article 36 (n. 1) of the Portuguese Local Finance Law (LFL), in force for the analyzed period ${ }^{7}$. It will therefore be calculated by the difference between the amount of financial liabilities (short-, medium- and long-term debts) and the amount of financial assets (short-, medium- and long-term amounts to be re- ceived from third parties, negotiable securities, bank deposits and cash balance) as of 31 December, divided by the total number of inhabitants. According to the LFL, the calculation of net debt should be consolidated, i.e., it should include the proportion of the municipality's participation in the capital of municipal associations and the local business sector. However, due to the difficulty of accessing information, this study will only consider the net debt of municipalities' individual accounts.

The hypotheses concerning the independent vari$a^{a b l e s}{ }^{8}$ are described and justified as follows. They draw from the literature, particularly the examples referred to in section 2.2 .

\section{I) Political ideology}

According to the theory of public choice, as a function of their political ideology, parties can present different objectives, and when in power in municipalities, they can follow policies that favor electors who supported them (Escudero Fernández and Prior Jiménez, 2002). Therefore, there may be differences with regard to expenditures carried out, which may lead to different levels of debt. In addition, considering the coercive isomorphism of institutional theory (Dimaggio and Powell, 1983), the pressure political parties put on the municipality leaders associated with them may also differentiate their action in relation to debt.

Although, as explained, the study of debt associated with political ideology is usually related to differentiation between left-wing/progressive and rightwing/conservative parties, there is no unanimity as to the relationship this differentiation can have with debt. Nevertheless, bearing in mind the political parties that normally lead Portuguese municipalities, we set out from the idea that, as left-wing parties have a greater tendency for public intervention, they will also be more likely to present greater expenditure, which may mean higher levels of debt. Therefore, the following hypothesis was formulated:

$\boldsymbol{H}_{\mathbf{I}}$ : Debt is greater in municipalities led by left-wing parties than in those led by right-wing parties

To distinguish between municipalities led by leftwing and right-wing parties, a dichotomic variable is used, taking the value 1 if the municipality is led by a left-wing party or coalition and 0 if the municipality is led by a right-wing party or coalition ${ }^{9}$. In cases 
of municipalities led by independents, an analysis of their leaders' political past was made to make a classification within the above-mentioned dichotomy. This procedure was adopted, as it was considered that, in many cases, independent leaders are party dissidents.

\section{II) Political cycle}

In the context of the public choice theory, various authors have attempted to establish a relationship between the political-electoral cycle and debt. As presented, they tried to validate the existence of what is known as 'strategic debt cycles'. The hypothesis usually considered is that in election periods, local Executives have a tendency to increase debt due to a greater tendency to increase expenditure. This occurs due to the attempt to maximize the probability of re-election or, on the other hand, as an attempt to limit their successor's actions.

The results obtained by Ribeiro and Jorge (2013) let us conclude that in the period 2004 to $2009^{10}$, there were strategic debt cycles in Portuguese local authorities. However, some authors confirm a negative relationship; that is, they do not validate the hypothesis of increased debt in pre-election and election years. As observed, Fernández Llera et al. (2004) explain this result by the possibility of the municipality often not having a majority, which hinders recourse to debt. This justification does not greatly apply to Portuguese municipalities, as relatively few are found to be led by a minority ${ }^{11}$.

Therefore, for more consistent validation, also based on the results of previous studies, which found that municipalities increase debt in election periods, the following hypothesis was put forward:

$\boldsymbol{H}_{2}$ : Municipalities' debt is greater in election years

In studying strategic debt cycles, many authors consider that the election period corresponds to the election year and the preceding year. However, during the period of analysis for this research, both local elections in Portugal were held in October. This fact led us to consider that increased net per capita debt could only occur in the election years. Therefore, to define political cycles, another dichotomic variable is used, taking the value 1 for the election year and 0 otherwise.

\section{III) Form of governance}

Salinas Jiménez and Álvarez García (2002; 2003), Vila i Vila (2010) and Sánchez Mier (2011) consider that a majority Executive will mean less yielding to the minority and therefore less need of resources. On the contrary, power-sharing will mean more concession and a greater need for resources, which could lead to greater debt.

Considering, in addition, the conclusions of Ashworth et al. (2005), Hagen and Vabo (2005), Borge (2005), Geys (2007), Tovmo (2007), Vila i Vila (2010), Zafra Gómez et al. (2011) and Letelier (2011), that coalition governments, being more fragmented and less strong politically, resort more to debt, a negative relationship with debt is expected in the case of a majority government; hence, the following hypothesis was established:

$\boldsymbol{H}_{3}$ : Debt is lower in municipalities led by a majority than in those led by a minority

Another dichotomic variable is defined to distinguish local authorities based on their form of governance, taking the value 1 for a majority government and 0 for a minority government.

\section{IV) Political party in the Executive coinciding with} that of the majority in the Municipal Assembly

As this hypothesis is not usual in the international literature, it seems important to consider it given the particularities of Portuguese municipalities, explained as follows.

As the Municipal Assembly operates as the first organ of (political) control of the Executive's action, it is assumed there could be greater difficulty in approving recourse to debt if the majority party does not coincide with the party in the Executive. Ideological reasons, budgetary constraints or other factors can lead the majority party in the Municipal Assembly, different from that of the Executive, to not approve recourse to debt. Moreover, according to the public choice theory, that majority can use their veto in an attempt to harm the action of the party leading the municipality and to maximize the possibility of a mayor from their party being elected to the Executive in the next election. It is therefore expected that when the parties coincide, there will be more recourse to debt. Hence, the hypothesis is as follows:

$\boldsymbol{H}_{4}:$ Debt is greater in municipalities where the political party in the Executive coincides with that of the majority in the Municipal Assembly

As for some of the previous hypotheses, a dichotomic variable was defined likewise, taking the value 
Table 1. Variables, form of calculation and expected relationship with debt

\begin{tabular}{|c|c|c|c|}
\hline Hypotheses & Variables & Form of calculation & $\begin{array}{l}\text { Expected } \\
\text { relation }\end{array}$ \\
\hline $\mathrm{H} 1$ & Political ideology (IDEOL) & $\begin{array}{l}1 \text { when municipalities are led by a left-wing party or } \\
\text { coalition } \\
0 \text { when municipalities are led by a right-wing party } \\
\text { or coalition }\end{array}$ & + \\
\hline $\mathrm{H} 2$ & Political cycle (CICEL) & $\begin{array}{l}1 \text { for election year } \\
0 \text { for other years }\end{array}$ & + \\
\hline H3 & Form of governance (FGOV) & $\begin{array}{l}1 \text { when municipalities are led by a majority Executive } \\
0 \text { when municipalities are led by a minority Executive }\end{array}$ & - \\
\hline $\mathrm{H} 4$ & $\begin{array}{l}\text { Political party of the Executive } \\
\text { coinciding with the majority } \\
\text { party in the Municipal } \\
\text { Assembly (COINCCMAM) }\end{array}$ & $\begin{array}{l}1 \text { when parties coincide } \\
0 \text { when parties do not coincide }\end{array}$ & + \\
\hline \multirow[t]{2}{*}{ H5 } & $\begin{array}{l}\text { Political party of the Executive } \\
\text { coinciding with the one } \\
\text { in Central Government } \\
\text { (COINCCMGC) }\end{array}$ & $\begin{array}{l}1 \text { when parties coincide } \\
0 \text { when parties do not coincide }\end{array}$ & \multirow[t]{2}{*}{-} \\
\hline & & Control variable & \\
\hline \multicolumn{2}{|c|}{ Crisis period (PCRISE) } & $\begin{array}{l}1 \text { for crisis period }(2008,2009 \text { e } 2010) \\
0 \text { for other years }\end{array}$ & + \\
\hline
\end{tabular}

1 when the political party of the Executive coincides with that of the majority in the Municipal Assembly and 0 otherwise. Coalitions are considered to coincide as long as one of the parties does.

\section{V) Political party of the local Executive coinciding} with the one in Central Government

Based on the public choice theory, various authors have approached the relationship between debt and coinciding parties in Local and Central Governments. As presented, the main idea is that, for political reasons, Central Government may financially benefit the local authority when parties coincide, increasing the amounts transferred and hence implying less recourse to debt from the latter. Still, some authors highlight the fact that the relationship may be ambiguous: Central Government may benefit Local Government, but it could also be more lenient with regard to control of debt limits.
In the specific case of Portuguese municipalities, the Local Finance Law sets out the general criteria for attributing transfers from Central to Local Government, which means differentiation can only be made in specific circumstances (program-contracts, agreements in specific areas, etc.). Nevertheless, it is believed that in the Portuguese case, there is a considerable likelihood of Central Government favoring financially certain municipalities, fundamentally through transfers, when the same party is in power. So, the following hypothesis is established:

$\boldsymbol{H}_{5}:$ Debt is lower in municipalities when the political party of the local Executive coincides with the party in Central Government

Also for this hypothesis, a dichotomic variable is defined, taking the value 1 when the political party of the Executive and the party in Central Government coincide and 0 otherwise. 


\section{VI) Crisis period (control variable)}

The time frame of analysis considered in this paper (2004-2013) embraces a period that is generally known as a worldwide financial crisis - the three-year period 2008-2010. It is commonly acknowledge that during these circumstances, the public sector debt level in general increased, as well as local authorities' debt. In the case of Portuguese municipalities, such a trend is shown by Carvalho et al. (2014). To catch this effect, a control dichotomic variable is defined, assuming the value 1 in those years and 0 in the others.

Table 1 summarizes the variables underlying the hypotheses (which were defined also based on the international literature and on the arguments presented above), the ways they are calculated and the expected relationship with debt.

\subsection{Statistical treatment}

The influence the political-ideological circumstances can have on debt in Portuguese municipalities is studied in this paper by using the methodology of panel data analysis. The models established are validated to find a final version.

Panel data analysis fits adequately with this type of study, as it allows simultaneous analysis of intermunicipal variations (sectional dimension) and over time (temporal dimension), in this case from 2004 to 2013. This methodology has been used by other authors, such as Kieweit and Szakaly (1996), López Laborda and Vallés Giménez (2002), Vallés Giménez, Pascual Arzoz, Cabasés Hita (2003), Fernández Llera et al. (2003), Hagen and Vabo (2005), Pascual Arzoz, Cabasés Hita and Roberto Ezcurra (2008) and Sánchez Mier (2011).

To begin with, as in Aparicio and Márquez (2005), models with pooled data are used and estimated by the Ordinary Least Squares (OLS) method. Homogeneity is therefore assumed in the constant part and in the slope of regressions for all municipalities.

The consideration that the constant is common for all municipalities as well as the slope is a quite restrictive condition. It is more realistic to consider that each municipality has its own characteristics, i.e., an individual character. Therefore, it is important to statistically consider the heterogeneity of individuals, and thus, both the fixed effects model and the random effects model in panel analysis are used.
In the fixed effects model, estimation is made assuming the heterogeneity of municipalities is captured in the constant part, which differs from one municipality to another. As for the random effects model, estimation is made considering the heterogeneity of municipalities in the error term; the constant is considered as a non-observable random parameter and not as a fixed parameter.

Once the above three models are defined, there is a need to carry out tests to define the model to use. The tests proposed by Breusch \& Pagan and the F test are performed to decide between the OLS model and the random effects and fixed effects model, respectively (Aparicio and Márquez, 2005). In addition, the Hausman test is used to decide which of the two models (random effects or fixed effects) is more appropriate.

After defining the model to use, the possible existence of problems of heteroskedasticity, contemporary correlation and autocorrelation is analyzed. For this purpose, the Wald Modification test, the Pesaran test and the Wooldridge test are performed (Aparicio and Márquez, 2005). If these problems exist, the Feasible Generalized Least Squares (FGLS) and the Panel Corrected Standard Errors (PCSE) estimators are used.

Considering that, as in Aparicio and Márquez (2005), the estimation with the PCSE model is revealed to be more efficient than with the FGLS model, the results obtained from that estimation are those to be used.

\section{Presentation of the results and discussion of the hypotheses}

The results of estimating the model using a pooled regression (OLS), Fixed Effects and Random Effects, as well as from performing the Breusch \& Pagan, $F$ and Hausman tests, are displayed in Table 2.

The results of the Breusch \& Pagan test lead to the rejection of the null hypothesis ( significance $=0.000$ ) that non-observable individual effects are relevant in explaining debt. Therefore, it can be concluded that it is preferable to use the estimation using the random effects model instead of the OLS. Carrying out the $F$ test (significance $=0.000$ ), in turn, leads to the observation that the fixed effects model should be used.

Considering the evidence that both the random effects and the fixed effects models are preferable to the OLS model, the Hausman test helps to decide which of 
the two to use. The results of the test indicate that one cannot reject the null hypothesis ( of absence of correlation between the non-observable individual effects and the explanatory variables. Therefore, the estimation must be performed using the random effects model, which is finally revealed as the most appropriate.

As explained previously, to check for the existence of problems related to the violation of independence when the errors of the different individuals are correlated (contemporary correlation), the errors for each individual are correlated in time (autocorrelation), and the "identical" distribution of the errors is violated when the variance is not constant (heteroskedasticity), the Pesaran, Wooldridge and Wald Modification tests were used. The results allow the conclusion that the estimations suffer from these problems, so to solve them, the Feasible Generalized Least Squares (FGLS) and Panel Corrected Standard Errors (PCSE) models were considered (results also displayed in Table 2). Aparicio and Márquez (2005) state that estimation with the PCSE is more rigorous because the standardized errors are more precise; hence, this is the estimated model finally considered, the results of which are going to be analyzed.

The results of the Wald test indicate (significance = 0.000 ) that the explanatory variables can be considered relevant in explaining municipalities' debt. Observing the estimation values, one can also conclude that two of the five independent variables, which present statistical significance, explain $57 \%\left(R^{2}=0.570\right)$ of the variation observed in municipal debt, i.e., the model has good explanatory power.

Concerning the political-ideological variables, the results displayed in Table 2 in the estimation with the PCSE model show statistical significance $(\alpha=0.05)$ only for CICEL. The control variable PCRISE is also found to present statistical significance ( $\alpha=0.1)$.

Considering the coefficients, it is not possible to corroborate hypothesis $\boldsymbol{H}_{\boldsymbol{1}}$ (IDEOL). On the contrary, there is some evidence, although not statistically significant, consistent with the results presented by Kieweit and Szakaly (1996), Pettersson-Lidbom (2001) and Ashworth et al. (2005), that left-wing parties present lower net per capita debt. Also in this study, as for Ashworth et al. (2005), this result was unexpected. However, it could indicate that political ideals are often not followed 'to the letter' by municipalities' leaders when in power. Their proximity to the population may make them act more as a function of needs rather than based on the ideals of the party that they were elected for. Consequently, one can state that the results are not consistent with the doctrine of public choice theory on which the hypothesis was founded.

As for the hypothesis related to the political cycle (CICEL), the results suggest that Portuguese municipalities increased debt in election years. This increase will possibly be related to the increased expenditure in the election year in an attempt to maximize the chance of re-election. One can therefore validate $\boldsymbol{H}_{2}$, the results being supported by the public choice theory, more specifically with strategic debt cycles. They are also consistent with those obtained by PetterssonLidbom (2001), Escudero Fernández and Prior Jiménez (2002b), Fernández Llera et al. (2003), Ashworth et al.(2005), Geys (2007), Agundez Alvarez and Baza Román (2008), Zafra Gómez et al. (2011), Ferreira (2011b), Letelier (2011), Bastida et al. (2013) and Ribeiro and Jorge (2013).

Regarding the form of governance (FGOV), one did not obtain statistically significant empirical evidence that would lead to corroborate hypothesis $\boldsymbol{H}_{3}$. Authors such as Feld and Kirchgässner (2001), Vallés Giménez (2002), López Laborda and Vallés Giménez (2002), Salinas Jiménez and Álvarez García (2002; 2003), Hájek and Hájková (2009) and Sánchez Mier (2011) did not find significant evidence either. Nevertheless, considering the negative sign of the coefficient, there seems to be a tendency for a majority Executive to mean less concession to the minority and therefore less need for financial resources, among them debt.

As for the variable COINCCMAM, the results are not statistically significant, so it is not possible to validate hypothesis $\boldsymbol{H}_{4}$ that debt is greater in municipalities when the political party of the Executive coincides with the majority in the Municipal Assembly.

In the same line as the results presented by López Laborda and Vallés Giménez (2002) and Fernández Llera et al. (2003), one did not obtain statistical significance that would allow validating hypothesis $\boldsymbol{H}_{5}$ on the relationship between debt and the political party of the local Executive coinciding with that of Central Government. However, the estimation of the model shows a negative sign for the variable COINCCMGC. This result suggests (although not significantly) that when 
Table 2. Results of the model estimation

\begin{tabular}{|c|c|c|c|c|c|c|c|c|c|c|}
\hline \multirow{2}{*}{ Variables } & \multicolumn{2}{|c|}{ OLS } & \multicolumn{2}{|c|}{ Random Effects } & \multicolumn{2}{|c|}{ Fixed Effects } & \multicolumn{2}{|c|}{ FGLS } & \multicolumn{2}{|c|}{ PCSE } \\
\hline & Coefficient & $\mathbf{T}$ & Coefficient & $t$ & Coefficient & $\mathbf{t}$ & Coefficient & z & Coefficient & $\mathbf{z}$ \\
\hline IDEOL & -0.061 & -1.689 & 0.011 & 0.244 & 0.035 & 0.698 & -0.026 & -0.051 & -0.047 & -1.154 \\
\hline CICEL & 0.054 & 1.458 & $0.050^{*}$ & 2.080 & $0.049^{*}$ & 2.067 & 0.174 & 1.166 & $0.085^{* *}$ & 2.831 \\
\hline FGOV & -0.063 & -1.132 & -0.095 & -1.758 & -0.100 & -1.797 & $5.494^{* * *}$ & 4.937 & -0.093 & -1.411 \\
\hline COINCCMAM & -0.053 & -0.581 & 0.112 & 1.472 & 0.128 & 1.648 & -0.224 & -0.199 & 0.024 & 0.377 \\
\hline COINCCMGC & -0.031 & -0.815 & -0.049 & -1.814 & -0.051 & -1.852 & 0.174 & 0.775 & -0.034 & -1.144 \\
\hline PCRISE & $0.196^{* * *}$ & 5.247 & $0.200^{* * *}$ & 7.954 & $0.200^{* * *}$ & 7.961 & 0.021 & 0.084 & $0.123^{*}$ & 2.544 \\
\hline CONS & $6.286^{* * *}$ & 61.982 & $6.127^{* * *}$ & 62.791 & $6.105^{* * *}$ & 67.468 & 0.000 & & $6.210^{* * *}$ & 58.071 \\
\hline Observations & 3080 & & 3080 & & 3080 & & 3080 & & 3080 & \\
\hline $\mathrm{R}^{2}$ & 0.010 & & 0.028 & & 0.028 & & & & 0.570 & \\
\hline Wald $\left(X^{2}\right)$ & & & $78.300^{* * *}$ & & & & $131.810^{* * *}$ & & $22.790^{* * *}$ & \\
\hline $\begin{array}{l}\text { Breusch \& } \\
\text { Pagan }\end{array}$ & & & $4895,960^{* * *}$ & & & & & & & \\
\hline F & $6.270 * * *$ & & & & $15.760^{* * *}$ & & & & & \\
\hline Hausman $\left(X^{2}\right)$ & & & 2.95 & & & & & & & \\
\hline
\end{tabular}

Note: (1) The Breusch \& Pagan test has $\chi 2$ distribution and tests the null hypothesis that non-observable individual effects are not relevant in explaining the dependent variable, against the alternative hypothesis of their relevance in explaining the dependent variable. (2) The Hausman test has $\chi 2$ distribution and tests the null hypothesis that non-observable individual effects are not correlated with the explanatory variables, against the alternative hypothesis of correlation between non-observable individual effects and the explanatory variables.(3) The Wald test has $\chi 2$ distribution and tests the null hypothesis of joint non-significance of the parameters of the explanatory variables against the alternative hypothesis of joint significance of the parameters of the explanatory variables. (4) The F test has normal distribution $N(0,1)$ and tests the null hypothesis of joint non-significance of the estimated parameters against the alternative hypothesis of joint significance of the estimated parameters. (5) * Statistical significance of 10\%; ${ }^{* *}$ statistical significance of $5 \%$; ${ }^{* * *}$ statistical significance of $1 \%$.

the political party of the Executive coincides with that of Central Government, municipality's debt is lower. This fact may be explained by the possibility of Central Government favoring municipalities of the same party through subsidies or transfers made within the scope of specific circumstances, such as program contracts and agreements in specific areas, which may diminish the need for debt.

Finally, the control variable (PCRISE), while statistically significant with a positive coefficient, demonstrates that, in the years of the financial crisis, Portuguese municipalities' debt also increased, hence supporting the descriptive analysis by Carvalho et al. (2014).

\section{Conclusion}

The aim of this research was to offer further insights to understand whether the local authorities' politicalideological situation influence their debt levels. To this end, using evidence from Portuguese municipalities in the period 2004 to 2013, various determinant factors of a political-ideological nature were studied. Given that the period of analysis embraced the years of worldwide financial crisis, the possible effects of this were also considered in the analysis.

After a review of the international literature, fundamentally based in the theory of public choice, a model was defined to be estimated using a methodology of 
panel data analysis, including five variables representing the municipalities' political-ideological setting, as well as a control variable for the effect of the financial crisis.

The results of estimating the model allow confirmation for only the political-electoral cycle, validating the existence of strategic cycles of debt in Portuguese municipalities, which means an empirical validation of the fact that net debt in municipalities presents higher values in election years, possibly due to a greater tendency to carry out expenditure, without increasing revenue from taxes, originating in the attempt to maximize the chances of re-election.

To try to avoid these cycles, Escudero Fernández and Prior Jiménez (2002) consider the possibility of extending the period of election cycles. However, we believe, as these authors do, that this approach to the problem would only produce results if the electoral period is infinite, which is something realistically impossible. Prevention of strategic debt cycles, in our opinion, could be achieved with the introduction of new and stricter rules related to debt limits, which could include creating limitations to relevant budgetary variations in forecasted revenue and expenditure, above all in periods of approaching elections.

Another mechanism to prevent strategic cycles of debt relates to better accountability. Portuguese municipalities must publish and disclose their annual accounts (including on their official website); often the accounts are independently audited (articles 48 and 49 of the LFL). However, we believe that the information reaching the electorate is extremely complex and does not provide information on the leader's action ${ }^{12}$. Electors should be informed in a simple and understandable way before the end of the legislature on various aspects, including indicators related to the evolution of debt. In Portugal, there is already the custom of some municipalities presenting flyers and brochures in which, among other aspects, they describe activities and investments that have been carried out, and so a detailed explanation of how they were financed would be of great interest. This information would allow the electorate to understand the effect of these measures on their future tax bill and also see whether leaders are behaving according to the electoral cycle.

As to the other political-ideological variables, they were not confirmed as statistically significant with regard to explaining debt levels in Portuguese munici- palities. These results seem to show that, except for the election-year effect, other political and ideological issues considered do not have a relevant effect on debt management at the local level, and so, the leader's action will be related more to the direct needs of the local population than to political-party orientations.

The variable to control the international financial crisis effect showed to be significant, with a positive impact on local authorities' debt, which increased in the period 2008-2010. This was possibly also related to the general context of financial difficulties that was already affecting Portugal, leading to the financial bailout by IMF-ECB-EC in 2011.

All in all, one cannot confirm that the politicalideological situation as a whole, at least as it has been defined in the variables in this paper for Portuguese municipalities, influences local authorities' debt levels because from the circumstances considered, only the electoral cycle is relevant. Still, the paper offers interesting lessons to be learned for other realities, especially other European countries, which might learn from the Portuguese context - the management of municipalities' debt seems to be driven by factors other than political ones, namely, endogenous economic issues (e.g., current expenditure and capital investment), which together with the electoral cycle seem to merit further analysis in future research.

From a methodological point of view, it could also be interesting to study the political-ideological determinants of local authorities' debt using dynamic panel data models, with the introduction of lagged variables $^{13}$, preferably with longer periods of analysis, which would possibly contribute to an increase in the robustness of the findings.

\section{References}

Aghion, P., \& Bolton, P. (1990). Government domestic debt and the risk of default: a political economic model of a strategic role of debt. In M. Dornbusch \& R. Draghi (Eds.), Public Debt Management: Theory and History (pp. 315-344). Cambridge, UK: Cambridge University Press.

Agundez Alvarez, Á., \& Baza Román, J. (2008, November). El Endeudamiento en los Ayuntamientos de Castilla y Leon: Un Estudio Empírico (2001-2005) [Indebtedness in the municipalities of Castilla y Leon: an empirical study (2001-2005)]. Paper pre- 
sented at the $11^{\text {th }}$ Economics Congress of Castila y León, Burgos.

Alesina, A., \& Tabellini, G. (1990). A positive theory of fiscal deficits and government debt. The Review of Economic Studies, 57 (3), 403-414.

Aparicio, J., \& Márquez, J. (2005). Diagnóstico y espacificación de modelos panel en STATA 8.0. [Diagnostics and especificacion of panel models in STATA 8.0.]. Retrieved from http://investigadores.cide.edu/aparicio/data/

Ashworth, J., Geys, B., \& Heyndels, B. (2005). Government Weakness and Local Public Debt Development in Flemish Municipalities. International Tax and Public Finance, 12 (4), 395-422.

Baltagi, B. (2005). Econometric analysis of panel data (3rd ed.). New York, NY: John Wiley \& Sons, Ltd.

Bastida Albadalejo, F., \& Benito López, B. (2005). Análisis del endeudamiento en los Ayuntamientos: un Estudio Empírico [Analysis of municipalities indebtedness: an empirical study]. Revista Española de Financiación Y Contabilidad, 34 (126), 613-635.

Bastida, F., Beyaert, A. \& Benito, B. (2013). Electoral Cycles and Local Government Debt Management. Local Government Studies, 39 (1), 107-132.

Benito, B., Bastida, F., \& Muñoz, M. (2010). Exploratory Factors of the Municipal Fiscal Burden. Spanish Accounting Review, 13 (2), 239-284.

Borge, L. (2005). Strong politicians, small deficits : evidence from Norwegian local governments. European Journal of Political Economy, 21 (1), 325-344.

Buchanan, J., \& Tullock, G. (1962). The calculus of consent: Logical foundations of constitutional democracy. Ann Arbor, MI: University of Michigan Press.

Carvalho, J., Fernandes, M., Camões, P., \& Jorge, S. (2014). Anuário Financeiro dos Municípios Portugueses 2013 [Financial Yearbook of Portuguese Municipalities 2013]. Lisbon: Câmara dos Técnicos Oficiais de Contas. Retrieved from http://www. cm-leiria.pt/uploads/writer_file/document/1195/ anuario.pdf

Diário da República. (2007, January 15). Local Finance Law. Official State Gazette no. 10, 1st series. Retrieved from https://dre.pt/application/file/522724

Dimaggio, J., \& Powell, W. (1983). The Iron Cage Revisited: Institutional Isomorphism and Collective Rationality in Organizational Fields. Amerrican Sociological Review, 48 (2), 147-160.
Guillamón, M. D., Benito, B., \& Bastida, F. (2011). Evaluación de la deuda pública local en España [Evaluation of local government debt in Spain]. Revista Española de Financiación Y Contabilidad, 40 (150), 251-285.

Escudero Fernández, P., \& Prior Jiménez, D. (2002). Endeudamiento y ciclos políticos presupuestarios: El caso de los ayuntamientos catalanes [Indebtedness and budgetary policy cycles: The case of Catalan municipalities] (Working Paper No. 2002/10). Barcelona.

Feld, L., \& Kirchgässner, G. (2001). Does direct democracy reduce public debt? Evidence from Swiss municipalities. Public Choice, 109 (3), 347-370.

Fernández Llera, R., García Valiñas, M., Cantarero Prieto, D., \& Pascual Sáez, M. (2003, November). El Endeudamiento de los Gobiernos Locales en España: Aspectos Generales y Resultados Empíricos [Indebtedness of Local Governments in Spain: general aspects and empirical results]. Paper presented at the $4^{\text {th }}$ Conference of the Galician Association of Public Sector Economic Studies, Santiago de Compostela.

Fernández Llera, R., García Valiñas, M., Cantarero Prieto, D., \& Pascual Sáez, M. (2004, February). Factores determinantes del endeudamiento de los Entes Locales. Una aplicación al caso español [Determinant factors of local authorities' debt. An application to the Spanish case]. Paper presented at the XI Public Economic Meeting of the University of Barcelona, Barcelona.

Ferreira, A. (2011a). Motivações do gestor e instrumentos contabilísticos utilizados na gestão dos resultados: o caso das autarquias locais [Manager motivations and accounting tools used in earnings management: the case of municipalities] (Unpublished doctoral dissertation). University of Aveiro, Aveiro.

Ferreira, F. (2011b). Determinantes do Endividamento Municipal em Portugal [Determinants of Municipal Debt in Portugal] (Unpublished master's thesis). University of Minho, Braga.

Geys, B. (2007). Government weakness and electoral cycles in local public debt: Evidence from Flemish municipalities. Local Government Studies, 33 (2), 237-251. 
Goeminne, S., \& Smolders, C. (2008, February). Vote expectations and pre-electoral tariff cuts in Flemish municipalities. Paper Presented at XVth Public Economics Meeting, University of Salamanca, Salamanca.

Hagen, T., \& Vabo, S. (2005). Political characteristics, institutional procedures and fiscal performance: Panel data analyses of Norwegian local governments, 1991-1998. European Journal of Political Research, 44 (1), 43-64.

Hájek, P., \& Hájková, V. (2009). Debt analysis of Czech municipalities. In F. Gyenes (Ed.), Scientific papers of the University of Pardubice. Faculty of Economics nad Administration (pp. 36-42). Pardubice: University of Pardubice.

Jorge, S., Moura e Sá, P., \& Lourenço, R. (2012). Transparência financeira nas entidades da administração local em Portugal: análise da informação disponibilizada nos sítios Web [Financial transparency in local government in Portugal: analysis of the information made available on websites]. RPER - Portuguese Review of Regional Studies, 31, 37- 51.

Kieweit, R., \& Szakaly, K. (1996). Constitutional Limitation on Borrowing: An Analisis of state Bonded Indebtedness. Journal of Law, Economics and Organization, 12 (1), 62-97.

Lami, E., \& Imami, D. (2013). Searching for Political Fiscal Cycles in Hungary. Contemporary Economics, 7 (4), 73-98.

Letelier, S. L. (2011). Theory and Evidence of Municipal Borrowing in Chile. Public Choice, 146 (3-4), 395-411.

López Laborda, J., \& Vallés Giménez, J. (2002). Evolución del endeudamiento autonómico entre 1985 y 1997: la incidencia de los Escenarios de Consolidación Presupuestaria y de los límites de la LOFCA. Papeles de Trabajo del Instituto de Estudios Fiscales, $n^{\circ}$. 2/2002. Madrid.

López Laborda, J., \& Vallés Giménez, J. (2002). Evolución del endeudamiento autonómico entre 1985 y 1997: la incidencia de los Escenarios de Consolidación Presupuestaria y de los límites de la LOFCA [Evolution of autonomous regions debt between 1985 and 1997: the impact of budgetary consolidation scenarios and LOFCA limits] (Working Paper No. 2/2002). Instituto de Estudios Fiscales, Madrid.
Martimort, D. (2001). Optimal Taxation and Strategic Budget Deficit under Political Regime Switching. Review of Economic Studies, 68 (3), 573-592.

Milesi-Ferreti, G. (1995). Do Good or Do Well? Public Debt Management in a Two-Party Economy. Economics and Politics, 7 (1), 59-78.

Mueller, D. (1976). Public choice: A Survey. Journal of Economic Literature, 14 (2), 395-433.

Mueller, D. (1993). The Public Choice Approach to Politics. Aldershot, UK: Edward Elgar.

Musgrave, R., \& Musgrave, P. (1989). Public Finance in Theory and Practice (5th ed.). New York, NY: McGraw-Hill.

Ostrom, V. (1971). The Political Theory of a Compound Republic. Blacksburg, VA: Public Choice Society.

Pascual Arzoz, P., Cabasés Hita, F., \& Roberto Ezcurra, R. (2008, February). Financiación, restricciones institucionales y endeudamiento: Un análisis con microdatos de los municipios de Navarra [Financing, institutional constraints and debt: An analysis with microdata from the municipalities of Navarra]. Paper presented at the XV Public Economic Meeting of University of Salamanca, Salamanca.

Pereira, P. (1997). A teoria da escolha pública (public choice): uma abordagem neoliberal? [The public choice theory (public choice): a neoliberal approach?]. Análise Social, 32 (141), 419-442.

Persson, T., \& Svensson, L. (1989). Why a Stubborn Conservative would Run a Deficit: Policy with Time-Inconsistent Preferences. The Quarterly Journal of Economics, 104 (2), 325-345.

Pettersson-Lidbom, P. (2001). An Empirical Investigation of the Strategic Use of Debt. The Journal of Political Economy, 109 (3), 570-583.

Ribeiro, N. (2012). Fatores determinantes do endividamento na administração local: o caso dos municípios portugueses [Determinant factors of local government debt: the Portuguese municipalities case] (Unpublished doctoral dissertation). Autonomous University of Madrid, Madrid.

Ribeiro, N., \& Jorge, S. (2013, September). O ciclo estratégico de endividamento nos municípios portugueses [Debt strategic cycle in Portuguese municipalities]. Paper presented at the XVII Congreso AECA of Spanish Association of Accounting and Business Administration, Pamplona. 
Rogoff, K. (1990). Equilibrium political budget cycles. The American Economic Review, 80 (1), 21-36.

Salinas Jiménez, J., \& Álvarez García, S. (2002, November). La Efectividad de los Límites al Endeudamiento Autonómico. Una Perspectiva de Teoría de la Elecccíon Pública [Effectiveness of the Autonomous Regions Debt Limits. A Perspective of the Public Eleccíon Theory]. Paper presented at the VIII Congreso de Economia Regional of Government of Castila y León, Valladolid.

Salinas Jiménez, J., \& Álvarez García, S. (2003, November). Los mecanismos de control del endeudamiento de los niveles subcentrales de gobierno. Análisis teórico y evidencia empírica del caso español [Control mechanisms of the debt of sub-central levels of government. Theoretical analysis and empirical evidence of the Spanish case]. Paper presented at the XXIX Reunión de Estudios Regionales of Spanish Association of Regional Science, Santander.

Sánchez Mier, M. (2011). Endeudamiento y ciclo politico-presupuestario: aplicación a los municipios asturianos [Indebtedness and political-budget cycle: application to the Asturian municipalities]. Presupuesto Y Gasto Público, 65, 75-96.

Serralde Miguez, S. (2000, February). El ciclo político presupuestario en las cc.aa. españolas (1984-1994) [The budget policy cycle in the Spanish autonomous regions (1984-1994)]. Paper presented at the VII Public Economic Meeting of University of Zaragoza, Zaragoza.

Sutter, M. (2003). The Political Economy of Fiscal Policy: An Experimental Study on the Strategic Use of Deficits. Public Choice, 116 (3-4), 313-332.

Tovmo, P. (2007). Budgetary Procedures and Deficits in Norwegian Local Governments. Economics of Governance, 8 (1), 37-49.

Vallés Giménez, J. (2002). Un Modelo explicativo de las causas del enseudamiento autonómico. El impacto de los límites de la ley orgánica de financiación de las comunidades autónomas [An explanatory model of the causes of autonomous regions indebtedness. The impact of the limits of the financing law of autonomous communities]. Revista Galega de Economía, 11 (1), 1-36.

Vallés Giménez, J., Pascual Arzoz, P., \& Cabasés Hita, F. (2003). Endeudamiento municipal y efectividad de las restricciones institucionales de disciplina crediticia (1988-2000) [Municipal debt and institutional constraints effectiveness of the credit discipline (1988-2000)]. Hacienda Pública Española/ Revista de Economía Pública, 166 (3), 9-47.

Veiga, L., \& Veiga, F. (2005). Eleitoralismo nos municípios portugueses [Electoralism in Portuguese municipalities]. Análise Social, 40 (177), 865-889.

Vila i Vila, J. (2010, February). Endeudamiento, gastos de inversión, y ciclo político presupuestario en las haciendas locales. el caso de los ayuntamientos valencianos [Debt, investment expenditure and budgetary policy cycle in local governments: the Valencian municipalities case]. Paper presented at the XVII Public Economic Meeting of University of Murcia, Murcia.

Zafra Gómez, J. L., Plata Díaz, A. M., \& Pérez López, G. (2009, September). Factores Determinantes de la deuda viva en los ayuntamientos. Una aplicación al caso español [Determinant factors of debt in the municipalities. An application to the Spanish case]. Paper presented at the XV Congreso AECA of Spanish Association of Regional Science, Valladolid.

Zafra Gómez, J., Plata Díaz, A., Pérez López, G., \& López Hernández, A. (2011, February). Influencia de los factores económico-financieros, políticos y de las formas de gestión sobre el nivel de la deuda viva en las entidades locales usando una metodología de datos de panel [Influence of economic, financial and political factors and ways of management on local authorities debt using a panel data methodology]. Paper presented at the XVIII Public Economic Meeting of University of Málaga, Málaga.

Zimmerman, J. (1977). The Municipal Accouting Maze: An Analysis of Political Incentives. Journal of Accounting Research, 15, 107-144.

\section{Endnotes}

1 This is especially important in the Portuguese context, in which a considerable amount of local debt relates to suppliers, apart from bank loans. Because local budgets and budgetary accomplishment are cash-based, debt to suppliers is not considered here, only cash inflows and outflows concerning loans.

2 Decree-Law n. 54-A/1999, of February 22.

3 Considering that agency theory is based fundamentally on the principles implicit in the theory of public 
choice, we chose not to develop the former autonomously.

4 This opposes the normative approach, which considers that the community (citizens) act and react as an "organic" body, based on commonly held values (Mueller 1993).

5 Ashworth et al. (2005) defined, among others, a variable where 1 represented a coalition government and 0 a single party. They also defined a variable considering the number of parties in the coalition. Note that for political strength, many authors use the Herfindahl index.

$6 \quad$ There were several data sources. Budgetary and $f i$ nancial data were gathered from the Local Government (official) Website (www.portalautarquico.pt) portalautarquico/); population data were gathered from the National Statistics Institute database ( $w w w$. ine.pt/xportal/xmain?xpid=INE\&xpgid=ine_ main); the website of the Elections National Commission (www.cne.pt) was used for data regarding election results.

$7 \quad$ Law n. 2/2007, January 15. In 2014, a new financial regime of municipalities and intermunicipal bodies came to practice, as set out in Law n. 73/2013, September 3 , for which the main changes compared to the previous one concerned the fact that the debt limit is now established in terms of gross (not net) amounts, as well as the requirement for municipalities' accounts to be audited.

8 All variables presented as a value in euros were converted as a function of the total number of inhabitants to allow comparison.

$9 \quad$ Socialist Party (PS), Portuguese Communist Party $(P C P)$, Left Block (BE) and Ecology Party "Greens" $(P E V)$ were considered left-wing parties. Social Democratic Party (PPD-PSD), CDS - Popular Party (CDS-PP) and Popular Monarchist Party (PPM) were considered right-wing parties.

10 In this period, local elections were held in 2005 and 2009.

11 Considering the period of analysis, only $10 \%$, on average, of municipalities were found to be led by minority Executives (www.cne.pt).

12 This seems to be confirmed by Jorge, Moura e Sá, \& Lourenço (2012).

13 According to Baltagi (2005), the introduction of these variables makes it possible to control the pos- sible correlation between past values of the dependent variable and contemporary values of the other explanatory variables, thus eliminating potential sources of estimator bias associated with that type of correlation. 